\title{
Examining some physical parameters of elite basketball players playing in different leagues
}

\section{Mehmet Fatih YUKSEL}

Department Physical Education and Sport, Faculty of Education, Necmettin Erbakan University, Konya, Turkey.

This research was presented the XIV. European Conference on Social and Behavioral Sciences in Odessa-Ukraine, 23-26 August 2017, as an oral presentation.

Correspondence address to M. F. Yuksel, e-mail; yukselmehmetfatih@gmail.com

\begin{abstract}
Objective of this study is to examine some physical parameters of basketball players at elite level who are playing in different league levels. Total 24 sportsmen consisting of 12 sportsmen from Turkish Man Basketball $2^{\text {nd }}$ League and 12 sportsmen from Turkey Men Basketball $3^{\text {rd }}$ league whose training age is minimum 5, voluntarily participated to this study. Vertical jumping, $20 \mathrm{~m}$ speed running, hand grip strength (right and left), flexibility, $30 \mathrm{sec}$ do sit-ups, 30 sec push-up, $20 \mathrm{~m}$ shuttle running tests were performed for determining physical properties of basketball players. It was determined that the $2^{\text {nd }}$ league basketball players had better hand grip strength (right-left), $\mathrm{Max} \mathrm{VO}_{2}$ and anaerobic power values than basketball players playing in the $3^{\text {rd }}$ league. Statistically significant difference was determined in $20 \mathrm{~m}$ speed running parameter $(\mathrm{p}<0.05)$. It was also determined that vertical jump, flexibility, $30 \mathrm{sec}$ do sit-ups and $30 \mathrm{sec}$ do push-up values were similar in two groups. Similarity which is observed in values of male basketball players who play in both leagues can be explained with proximity at rivalry levels between leagues. This proximity at competition level which is observed between particularly $2^{\text {nd }}$ and $3^{\text {rd }}$ leagues are projected in physical profiles of players. In addition to this differences which are seen in some parameters may be caused from differences in training programs. It is considered that technical, tactical and psychological properties of players are important for determining players between leagues in addition to physical properties.
\end{abstract}

Keywords: Basketball, different leagues, physical parameters.

\section{INTRODUCTION}

Basketball, which can be played by all age groups, is the second most favorite sport branch after football in Turkey. Moreover, it should be remembered that basketball is a struggle sport which necessitates technique-tactic and psycho-mental features, and where some motoric features like power, speed and endurance gain importance $(5,13,22)$.

As it was mentioned that the motoric requisites of the positions of players in the game can create differences in physical fitness compounds (20), there are also studies stating that players in different positions can have similar physical features (15). Besides, factors such as beginning the game in the first five, entering afterwards, or total playing times of the players were reported to have no effect on physical fitness of the player (16). It is difficult to attribute success to only one factor in basketball $(7,25)$. However, being tall, which is a dimension of physical structure, was accepted to be an advantage (4).

In the studies conducted, anthropometric and physiologic profiles of the successful basketball players were evaluated, and factors such as experience, body composition, endurance, balance between aerobic and anaerobic power were determined to be prior within others in the evaluation of elite level basketball players $(10,23)$. Moreover, there are studies supporting that improving power and anaerobic power capacities is a must for success in basketball $(19,21)$.

Together with numerous useful studies about basketball sport branch, it is also important to compare the motoric features of basketball players playing in different league levels, and to examine whether there are any differences. The aim of this research is to examine some physical parameters of elite level basketball players playing in different league levels. 


\section{MATERIALS \& METHODS}

In this study, 12 basketball players from Turkey Men's Basketball $2^{\text {nd }}$ League (average age; $24.25 \pm 5.23$ ) and 12 basketball players from Turkey Men's Basketball $3^{\text {rd }}$ League (average age; 18.75 \pm 2.93 ), totally 24 basketball players, whose practice age was at least five, participated voluntarily. All of the tests and measurements were recorded in the interval period of the league, and necessary information about the tests was explained to the players before the applications. Vertical jumping values, anaerobic power, and $20 \mathrm{~m}$ shuttle run values of players were tested, and maximum oxygen utilization capacities $\left(\mathrm{MaxVO}_{2}\right)$ were determined. 15 min warm up period was applied before the tests. In each test battery 2 tests were made with 5-10 min intervals and best values were recorded, except for the $30 \mathrm{sec}$ sit-ups and $20 \mathrm{~m}$ shuttle run.

\section{Tests Applied}

Height and Body weight: In the linear measurements a tapeline with $0.01 \mathrm{~m}$ sensitivity score was used. Weight measurements were made with a digital weighing scale with a sensitivity level of 0.01 $\mathrm{kg}(27)$.

Body mass index (BMI): Using body weights and lengths, BMI was determined using the BMI = Body weight / (Length) $)^{2}$ formula (18).

Sit and reach test: was determined on the sit and reach platform, and recorded in $\mathrm{cm}(9)$.

Hand Grasping Strength: Beginning from the right hand, the measurement was made with Jamar brand dynamometer and recorded in $\mathrm{kg}$, while the subject was on foot, arm straight with a 10-15o angle from the shoulder on one side (9).

$30 \mathrm{sec}$ Sit-ups test: The soles of the feet are fully on the mat, knees bent $\left(90^{\circ}\right)$, hands are on each side and touching the neck, in a sitting position on the mat and the counts were recorded as the elbows touched the knees for 30 seconds (27).

30 sec push up test: The subjects were positioned as hands are on the gymnastic mat open in shoulder width, elbows are straight, knees do not touch to the ground and lumbar region does not bend down. With the start sign, the player approached his body $90^{\circ}$ to the ground and each count recorded as he returned to the starting position (18).

Balance measurement; Balance scores were determined with Flamingo Balance device. Test lasted for one minute and at the end of the time, each balance attempt of the subject was counted and recorded as the balance result (26).

$20 \mathrm{~m}$ speed test: A course with a 20-meter straight running track was prepared in the hall. The time between start and end was determined with NewTest 2000 photocell device and recorded in sec (2).

Vertical jump test: Determined using the vertical jumping gauge (9).

Anaerobic power measurement: Measurements of body weight with vertical jump distance (m) were determined by the Lewis formula using the resulting values (9).

$(P=\sqrt{ } 4.9$ * Body weight * $\sqrt{D}) \mathrm{P}=$ Anaerobic Power, $\mathrm{D}=$ Vertical jump distance $(\mathrm{m})$.

Determining $\mathrm{MaxVO}_{2} ; 20 \mathrm{~m}$ shuttle run test was applied, and the number of the runs that the subject performed were used on evaluation table, thus $\mathrm{MaxVO}_{2}$ values were determined and recorded in $\mathrm{ml} / \mathrm{kg} / \mathrm{min}(9)$.

Table 1. Average values of the research group according to the leagues.

\begin{tabular}{|c|c|c|c|c|}
\hline Variables & League & $\mathrm{N}$ & Mean & SD \\
\hline \multirow[t]{2}{*}{ Age } & $2^{\text {nd }}$ & 12 & 24.25 & 5.23 \\
\hline & $3^{\text {rd }}$ & 12 & 18.75 & 2.93 \\
\hline \multirow[t]{2}{*}{ Height } & $2^{\text {nd }}$ & 12 & 196.08 & 8.74 \\
\hline & $3^{\text {rd }}$ & 12 & 194.58 & 7.65 \\
\hline \multirow[t]{2}{*}{ Weight } & $2^{\text {nd }}$ & 12 & 96.67 & 11.83 \\
\hline & $3^{\text {rd }}$ & 12 & 93.00 & 10.34 \\
\hline \multirow[t]{2}{*}{ BMI } & $2^{\text {nd }}$ & 12 & 25.06 & 1.44 \\
\hline & $3^{\text {rd }}$ & 12 & 24.49 & 1.21 \\
\hline \multirow{2}{*}{$\begin{array}{l}\text { Hand Grasping Strength } \\
\text { (right) }\end{array}$} & $2^{\text {nd }}$ & 12 & 55.92 & 1077 \\
\hline & $3^{\text {rd }}$ & 12 & 51.91 & 8.23 \\
\hline \multirow{2}{*}{$\begin{array}{l}\text { Hand Grasping Strength } \\
\text { (left) }\end{array}$} & $2^{\text {nd }}$ & 12 & 54.93 & 11.21 \\
\hline & $3^{\text {rd }}$ & 12 & 50.82 & 8.40 \\
\hline \multirow[t]{2}{*}{ Vertical jump } & $2^{\text {nd }}$ & 12 & 45.00 & 5.12 \\
\hline & $3^{\text {rd }}$ & 12 & 44.83 & 7.11 \\
\hline \multirow[t]{2}{*}{ Anaerobic power } & $2^{\text {nd }}$ & 12 & 142.87 & 14.87 \\
\hline & $3^{\mathrm{rd}}$ & 12 & 137.19 & 16.21 \\
\hline \multirow[t]{2}{*}{ Sit and reach } & $2^{\text {nd }}$ & 12 & 23.75 & 3.79 \\
\hline & $3^{\text {rd }}$ & 12 & 21.42 & 5.14 \\
\hline \multirow[t]{2}{*}{30 sec sit-ups } & $2^{\text {nd }}$ & 12 & 23.58 & 4.46 \\
\hline & $3^{\text {rd }}$ & 12 & 23.67 & 3.85 \\
\hline \multirow[t]{2}{*}{30 sec push-up } & $2^{\text {nd }}$ & 12 & 24.67 & 3.26 \\
\hline & $3^{\text {rd }}$ & 12 & 24.33 & 4.42 \\
\hline \multirow[t]{2}{*}{$20 \mathrm{~m}$ speed } & $2^{\text {nd }}$ & 12 & 3.25 & 0.28 \\
\hline & $3^{\text {rd }}$ & 12 & 3.50 & 0.24 \\
\hline \multirow[t]{2}{*}{$\mathrm{Max} \mathrm{VO}_{2}$} & $2^{\text {nd }}$ & 12 & 52.38 & 5.40 \\
\hline & $3^{\text {rd }}$ & 12 & 47.70 & 5.27 \\
\hline
\end{tabular}

\section{Statistical analysis}

SPSS 21.0 program was used in the analysis of the data obtained in the study. Arithmetic averages 
and standard deviations were given with descriptive statistics. The inter-group differences were detected via Mann-Whitney U test. Significance level was admitted as $\mathrm{p}<0.05$.

Table 2. Mann Whitney-U Analysis of the research group according to the leagues.

\begin{tabular}{|c|c|c|c|c|}
\hline Variables & League & $\begin{array}{c}\text { Mean } \\
\text { Rank }\end{array}$ & $\mathrm{U}$ & $\mathrm{p}$ \\
\hline \multirow[t]{2}{*}{ Age } & $2^{\text {nd }}$ & 16.42 & 25.000 & $0.006^{*}$ \\
\hline & $3^{\text {rd }}$ & 8.58 & & \\
\hline \multirow[t]{2}{*}{ Height } & $2^{\text {nd }}$ & 13.21 & 63.500 & 0.623 \\
\hline & $3^{\text {rd }}$ & 11.79 & & \\
\hline \multirow[t]{2}{*}{ Weight } & $2^{\text {nd }}$ & 13.38 & 61.500 & 0.544 \\
\hline & $3^{\text {rd }}$ & 11.63 & & \\
\hline \multirow[t]{2}{*}{ BMI } & $2^{\text {nd }}$ & 13.92 & 55.000 & 0.326 \\
\hline & $3^{\text {rd }}$ & 11.08 & & \\
\hline Hand Grasping & $2^{\text {nd }}$ & 13.96 & 54.500 & 0.312 \\
\hline Strength (right) & $3^{\text {rd }}$ & 11.04 & & \\
\hline Hand Grasping & $2^{\text {nd }}$ & 13.83 & 56.000 & 0.356 \\
\hline Strength (left) & $3^{\text {rd }}$ & 11.17 & & \\
\hline \multirow[t]{2}{*}{ Vertical jump } & $2^{\text {nd }}$ & 13.33 & 62.000 & 0.563 \\
\hline & $3^{\text {rd }}$ & 11.67 & & \\
\hline \multirow[t]{2}{*}{ Anaerobic power } & $2^{\text {nd }}$ & 13.92 & 55.000 & 0.326 \\
\hline & $3^{\text {rd }}$ & 11.08 & & \\
\hline \multirow[t]{2}{*}{ Sit and reach } & $2^{\text {nd }}$ & 14.50 & 48.000 & 0.164 \\
\hline & $3^{\text {rd }}$ & 10.50 & & \\
\hline \multirow[t]{2}{*}{30 sec sit-ups } & $2^{\text {nd }}$ & 12.88 & 67.500 & 0.794 \\
\hline & $3^{\text {rd }}$ & 12.13 & & \\
\hline \multirow[t]{2}{*}{30 sec push-up } & $2^{\text {nd }}$ & 13.33 & 62.000 & 0.561 \\
\hline & $3^{\text {rd }}$ & 11.67 & & \\
\hline \multirow[t]{2}{*}{$20 \mathrm{~m}$ speed } & $2^{\text {nd }}$ & 9.33 & 34.000 & $0.028^{*}$ \\
\hline & $3^{\text {rd }}$ & 15.67 & & \\
\hline \multirow[t]{2}{*}{$\mathrm{Max} \mathrm{VO}_{2}$} & $2^{\text {nd }}$ & 15.25 & 39.000 & 0.057 \\
\hline & $3^{\text {rd }}$ & 9.75 & & \\
\hline
\end{tabular}

\section{RESULTS}

When the average values of the $2^{\text {nd }}$ League and $3^{\text {rd }}$ League basketball players were examined, it was determined that there was statistically significant difference in age and $20 \mathrm{~m}$ speed parameters $(p<0.05)$; however, there was no statistically significant difference between leagues in terms of stature, body weight, body mass index, grasping power (right-left hand), vertical jumping, anaerobic power, flexibility, $30 \mathrm{sec}$ sit-ups, $30 \mathrm{sec}$ push-ups, and $\mathrm{MaxVO}_{2}$ values $(\mathrm{p}>0.05)$.

\section{DISCUSSION}

This study was conducted to examine some physical parameters of elite level basketball players playing in different league levels.

In the study conducted, it was determined that the basketball players playing in the $2^{\text {nd }}$ League were older, taller, heavier, and with higher BMI's compared to the players of the $3^{\text {rd }}$ League; however, there was no statistically significant difference in between the average values of the leagues except age.

Pamuk et al. (21) determined that the average hand grasping value of the $2^{\text {nd }}$ League basketball players was $45.56 \mathrm{~kg}$, while it was 36.82 for the regional league basketball players, and reported that there was statistically significant difference between the leagues. In our study, it was observed that the values of the $2^{\text {nd }}$ League players were better as well; however, there was no statistically significant difference. It is evaluated that this was because of the closeness of the leagues.

In the study conducted, it was observed that flexibility, 30 sec sit-ups, 30 sec push-ups, and vertical jumping average values were similar to each other. It was reported that $30 \mathrm{sec}$ sit-up and push-up average values of university students with an age average of 21.3 was 26.2 and 25.9 respectively (1). In another study on male basketball players in university, flexibility average values of pivot and forward players were reported as respectively $10.83 \mathrm{~cm}$ and $10.67 \mathrm{~cm}$; vertical jumping average values as $44.25 \mathrm{~cm}$ and $42.33 \mathrm{~cm}$ (15). In another study on a similar group, vertical jumping average values of pivot, forward, and point guard male university basketball players were respectively recorded as $56.34 \mathrm{~cm}, 64.27$ $\mathrm{cm}$ and $68.12 \mathrm{~cm}$ (19); in another research on basketball players, flexibility value was determined as $24.2 \mathrm{~cm}$ before the short camp period with intense exercises (14). Although the flexibility and vertical jumping values do not correspond with certain studies $(15,19)$, it can be mentioned that they were supported by other sources $(1,8,11-12,14,21)$.

When the results of anaerobic power, $\mathrm{Max} \mathrm{VO}_{2}$, and $20 \mathrm{~m}$ speed are examined, it was determined that $2^{\text {nd }}$ League players had better average values, and that there was statistically significant difference with regards to $20 \mathrm{~m}$ speed parameter. Despite similar values in vertical jumping of $2^{\text {nd }}$ and $3^{\text {rd }}$ League players, $2^{\text {nd }}$ League players reaching higher values could be resulted from their body weight excess. In a similar study on elite basketball players, $20 \mathrm{~m}$ speed average values were reported as $3.47 \mathrm{sec}$ before the exercise camp and $3.14 \mathrm{sec}$ after the camp (1), and they supported the results of our study; while it was determined $3.07 \mathrm{sec}$ in elite level football players and 3.06 in handball players (11). This difference in team sports with similar energy systems could be either a result of the variables at the moment of measuring and testing, or a result of more time being allocated to speed practices in the exercise phases of the other sport branches. Average $\mathrm{MaxVO}_{2}$ value of the $2^{\text {nd }}$ 
League players of the research was recorded as 52.38 $\mathrm{ml} / \mathrm{kg} / \mathrm{min}$, while it was recorded as $47.70 \mathrm{ml} / \mathrm{kg} / \mathrm{min}$ for the $3^{\text {rd }}$ League players. The $\mathrm{MaxVO}_{2}$ results found in the literature review $(3,11,15,21,24)$ are supporting our findings. Regarding $2^{\text {nd }}$ and $3^{\text {rd }}$ League basketball players of our research, higher values were observed both in $20 \mathrm{~m}$ speed and $\mathrm{MaxVO}_{2}$ average in favor of the $2^{\text {nd }}$ League players, which was thought to be a result of more regular and special speed and endurance practices.

It could be accepted as a deficiency of the study that the basketball players were not evaluated according to their positions in the game (point guard, pivot, forward etc.). Besides, it is thought to be more useful that similar future researches be conducted with more participants and evaluated with other physical parameters.

As a conclusion, similarity in the values of male basketball players in both league levels can be explained with the proximity of competition levels of Turkish Basketball Leagues. It can be mentioned that this proximity in the competition levels reflected on physical profiles of the players. It is reported that as physiologic and anatomic maturity is completed in professional players, the differences in motoric features diminishes (17), and this principle is parallel with the findings of the study conducted. It is thought that the reason of $2^{\text {nd }}$ and $3^{\text {rd }}$ league level players being in different leagues is because of technique, tactic, and psychological features rather than physical characteristics. Besides, differences observed in some parameters could be stemmed from the differences in exercise programs.

\section{REFERENCES}

1. Bakırcı A, K1lınç F. The effect of applied combined training in the preparatory periods on the performance level of the university basketball team. Inonu University, Journal of Physical Education and Sport Sciences, 2014; 1(2): 48-67.

2. Bogdanis GC, Nevill ME, Lakomy HKA, Boobis LH. Power output and muscle metabolism during and following recovery from 10 and $20 \mathrm{~s}$ of maximal sprint exercise in humans. Acta Physiol Scand, 1998; 163: 261-272.

3. Büyükyazı G, Sevim Y. Farklı aerobik antrenman programlarının 15-16 yaş grubu erkek basketbolcuların aerobik ve anaerobik güçleri üzerine etkileri. Ege Üniversitesi Spor Hekimliği Dergisi, 2000; 1: 19-28.

4. Carter JEL, Ackland TR, Kerr DA, Stapff AB. Somatotype and size of elite female basketball players. Journal of Sports Sciences, 2005; 23(10): 1057-1063.

5. Drinkwater EJ, Pyne DB, McKenna MJ. Design and interpretation of anthropometric and fitness testing of basketball players. Sports Medicine, 2008; 38: 565-578.
6. Fox EL, Bowers RW, Foss LM. The physiological basis of physiol education and athletics. Sounders College Publishing, 1988.

7. Gocentas A, Landõr A, Andziulis A. Dependence of intensity of specific basketball exercise from aerobic capacity. Papers on Anthropology, 2004; 13: 9-17.

8. Gökdemir H. Farklı branşlardaki erkek futbolcuların fiziksel ve fizyolojik özelliklerinin karşılaştırılması. Selçuk Üniversitesi Beden Eğitimi ve Spor Bilimleri Dergisi, 1999; 1(1): 16-19.

9. Günay M, Tamer K, Cicioğlu İ. Spor Fizyolojisi ve Performans Ölçümü. 3. Baskı. Ankara: Gazi Kitabevi, 2013.

10. Hoffman JR. Physiology of basketball. In: Basketball. McKeag, D. B., (ed.) Oxford: Blackwell Science, 2003.

11. İri R, Yılmaz A, Aktuğ ZB. The comparison of physical fitness levels and motoric features of elite footballers and handball players. Journal of Sports and Performance Researches, 2017; 8(1): 19-25.

12. Kartal A, Kartal R, İrez GB. Investigate of some motor functions according to soccer players playing positions. CBU J Physical Education and Sport Sciences, 2016; 11(1): 55-62.

13. Kılınç F. An intensive combined training program modulates physical, physiological, biomotoric and technical parameters in basketball player women. J Strength and Conditioning Research, 2008; 22: 1064-1068.

14. Kılınç F, Koç H, Erol AE, Pulur A, Gelen E. Male stars camp period biomotoric of basketball and the intense training applied technical effects on performance. International Journal of Human Sciences, 2011; 8(1): 213-229.

15. Küçük H, Doğan E, Taşmektepligil MY. The Comparision of selected physiological of basketball players according to their playing positions. KAU Journal of the Institute of Social Sciences, 2014; 13: 65-71.

16. Ladwig E, Shim A, Yom J, Cross P, Beebe J. Preseason and postseason body composition does not change relative to playing time in division female basketball players. International Journal of Exercise Science, 2013; 6(3): 208-216.

17. Macardle W, Katch F, Katch V. Exercise Physiology Energy, Nutrition and human Performance. Eighth Edition. Lippincott Williams \& Wilkins, Baltimore, 2015.

18. Mackenzie B. 101 Performance Evaluation Tests. Electric Word plc. London, 2005.

19. Menevşe A. The comparison of anaerobic powers of basketball players considering their player positions. Journal of Sports and Performance Researches, 2013; 4(1): 33-37.

20. Mercadante LA, Panhan AC, Monezi LA, Gaspar RS, Misuta MS. Distance covered in different game situations by highlevel basketball players from brazil. ISBS-Conference Proceedings Archive, 2014.

21. Pamuk Ö, Kaplan T, Taşkın H, Erkmen N. Examination of the some physical and physiological parameters on basketball players according to different leagues. Spormetre: J Physical Education and Sport Science, 2008; 6(3): 141-144.

22. Sampaio J, Drinkwater EJ, Leite NM. Effects of season period, team quality, and playing time on basketball players' gamerelated statistics. European Journal of Sport Science, 2010; 10(2): 141-149. 
23. Scheller A, Rask B. A protocol for the health and fitness assessment of NBA players. Clin Sports Med, 1993; 12: 193-205.

24. Tamer K, Koç H. Hentbol, basketbol ve voleybol takımlarındaki erkek sporcuların aerobik ve anaerobik güçlerinin karşılaş̧ııılması. Dumlupınar Üniversitesi Sosyal Bilimler Dergisi, 1999; 1: 263-270.

25. Trninic S, Dizdar D. System of the performance evaluation criteria weighted perpositions in the basketball game. Collegium Antropologicum, 2000; 24(1): 217-234.
26. Tsigilis N, Douda H, Tokmakidis SP. Test-retest reliability of the Eurofit Test Battery administered to university students. Perceptual and Motor Skills, 2002; 95: 1295-1300.

27. Zorba E, Saygın Ö. Fiziksel Aktivite ve Fiziksel Uygunluk. (2. Bask1). İstanbul: İnceler Ofset, 2009. 